\title{
Cyclic AMP-Responsive Element-Binding Protein 5
}

National Cancer Institute

\section{Source}

National Cancer Institute. Cyclic AMP-Responsive Element-Binding Protein 5. NCI

Thesaurus. Code C38543.

Cyclic AMP-responsive element-binding protein 5 (508 aa, $\sim 57 \mathrm{kDa}$ ) is encoded by the human CREB5 gene. This protein is involved in transcriptional regulation. 